\title{
The effect of moderately and severely restricted dietary magnesium intakes on bone composition and bone metabolism in the rat
}

\author{
Annette Creedon, Albert Flynn and Kevin Cashman* \\ Department of Nutrition, University College, Cork, Republic of Ireland
}

(Received 23 September 1998 - Revised 29 December 1998 - Accepted 8 March 1999)

\begin{abstract}
Forty 3 -week-old male rats, Wistar strain, average weight $59 \mathrm{~g}$, were randomized by weight into five groups of eight rats each. Three groups were fed ad libitum on a semi-purified diet containing (per kg) 400 (adequate), 200 (moderately Mg-restricted) or 20 (severely Mg-restricted) mg Mg for 3 weeks while two groups were pair-fed with the $\mathrm{Mg}$-adequate diet in the same quantities as those consumed by the two Mg-restricted groups respectively. While weight gains and food conversion efficiency values for the Mg-restricted groups were similar to those of the corresponding pair-fed control groups, serum and kidney $\mathrm{Mg}$, and femoral dry weight were reduced by 70, 7 and $9 \%$ respectively in the severely $\mathrm{Mg}$-restricted group and were unaffected in the moderately $\mathrm{Mg}$-restricted group. Significant reductions were observed in urinary pyridinoline (Pyr) (by 44 and $34 \%$ ) and deoxypyridinoline (Dpyr) levels (by 40 and 33\%) (markers of bone resorption), serum osteocalcin levels (by 46 and $28 \%$ ) (marker of bone formation), femoral Mg levels (by 52 and 14\%) and osteocalcin mRNA levels (by 46 and 22\%) compared with the corresponding pair-fed controls, in the severely and moderately $\mathrm{Mg}$-restricted groups respectively, and these reductions, except for those in urinary Pyr and Dpyr, were more marked in the severely Mg-restricted group. Femoral $\mathrm{Ca}$ and $\mathrm{P}$ concentrations were unaffected by dietary $\mathrm{Mg}$ restriction. These results show that not only severe but also moderate dietary restriction of $\mathrm{Mg}$ over $21 \mathrm{~d}$ results in qualitative changes in bone (i.e. reduced $\mathrm{Mg}$ concentration) as well as in aberrant bone turnover in young growing rats (i.e. severely depressed rates of bone formation and bone resorption), which may impair bone development and bone strength.
\end{abstract}

Magnesium: Biochemical markers: Bone

Mg plays a major role in bone and mineral homeostasis and can also directly affect bone cell function as well as influence hydroxyapatite crystal formation and growth (Cohen, 1988). Mg deficiency has been suggested as a possible risk factor for osteoporosis in man (Institute of Medicine, 1997; Rude, 1998). Several studies have reported significant reductions in serum $\mathrm{Mg}$ and bone $\mathrm{Mg}$ content in postmenopausal women with osteoporosis (Manicourt et al. 1981; Cohen, 1988; Reginster et al. 1989; Cohen \& Laor, 1990; Stendig-Lindberg et al. 1993). Recently, elderly women who consumed less than $187 \mathrm{mg} \mathrm{Mg} / \mathrm{d}$ were found to have a significantly lower bone mineral density than women whose average dietary $\mathrm{Mg}$ intake was more than $187 \mathrm{mg} / \mathrm{d}$ (Tucker et al. 1995).

While Mg deficiency sufficiently severe to produce clinical symptoms is very rare in human subjects (Héroux et al. 1975), there is evidence that many individuals in Western countries have intakes of $\mathrm{Mg}$ which are significantly below the recommended levels (Gregory et al. 1990; Van Dokkum, 1995; Cleveland et al. 1996). This raises the possibility that a state of mild deficiency might result from suboptimal intakes of $\mathrm{Mg}$ with consequences for bone health. However, to date little research emphasis has been placed on this issue.

It is known that several aberrations in bone mineral homeostasis and bone metabolism result as a consequence of severe $\mathrm{Mg}$ deficiency in experimental rats. These include reduced bone growth and bone volume (Wallach, 1990; Carpenter et al. 1992), and increased skeletal fragility (Lai et al. 1975; Kenney et al. 1994), together with increased (Jones et al. 1980; Kenney et al. 1994; Planells et al. 1995), or unchanged (Clark \& Belanger, 1967) bone Ca content. Furthermore, there have been a number of reports of an association between severe $\mathrm{Mg}$-deficiency and abnormal bone formation (Jones et al. 1980; Boskey et al. 1992; Carpenter et al. 1992). For example, Carpenter et al. (1992) showed that feeding a Mg-deficient diet (20 mg/kg diet) for $12 \mathrm{~d}$ to young growing rats led to a $38 \%$ reduction in serum osteocalcin, a marker of bone formation, compared with that of Mg-replete animals. Furthermore, Boskey et al. (1992) found that the osteocalcin content of the metaphyseal bone 
of severely Mg-deficient animals was significantly less than that of Mg-replete animals.

Reduced urinary excretion of hydroxyproline, a marker of bone resorption, has also been associated with severe $\mathrm{Mg}$ deficiency in rats (MacManus \& Heaton, 1969; Rayssiguier \& Larvor, 1978). For example, MacManus \& Heaton (1969) showed that rats fed on a $\mathrm{Mg}$-deficient diet $(3 \mathrm{mg} / \mathrm{kg}$ diet) had significantly lower rates of hydroxyproline excretion compared with rats fed on a $\mathrm{Mg}$-adequate diet $(780 \mathrm{mg} / \mathrm{kg})$, suggesting that severe $\mathrm{Mg}$ deficiency affects the rate of bone resorption. There has been no study of the effect of $\mathrm{Mg}$ deficiency on the rate of bone resorption, as assessed by the urinary excretion of pyridinium crosslinks which are regarded as more specific markers of bone resorption in rats (Black et al. 1989; Egger et al. 1994).

However, much of the knowledge concerning the effect of $\mathrm{Mg}$ deficiency on bone is based primarily on observations on growing animals fed on diets which were severely restricted in $\mathrm{Mg}$, i.e. containing between 3 and $100 \mathrm{mg}$ $\mathrm{Mg} / \mathrm{kg}$ diet (MacManus \& Heaton, 1969; Lai et al. 1975; Jones et al. 1980; Boskey et al. 1992; Carpenter et al. 1992; Kenney et al. 1994; Vormann et al. 1997). There is very little, if any, information on the effect of moderate $\mathrm{Mg}$ depletion on either bone composition or bone metabolism in the rat. Reduced levels of $\mathrm{Mg}$ in bone have been reported in rats fed on a moderately restricted intake of $\mathrm{Mg}$ (120-200 mg Mg/kg diet) for periods of 70-500 d (Héroux et al. 1975; Lerma et al. 1993).

Thus, the aim of the present study was to investigate the effects of moderate and severe restriction of dietary $\mathrm{Mg}$ on bone composition and on bone metabolism in a rat model.

\section{Materials and methods}

\section{Preparation of rat diets}

The AIN-76 purified diet (American Institute of Nutrition, 1977) was used in the present study (Table 1).

\section{Experimental design}

Forty male rats, 3 weeks old, Wistar strain (average weight $58.8 \mathrm{~g}$ ), obtained from the Biological Services Unit, University College, Cork, were randomized by weight into five groups of eight rats each. Three groups were fed ad libitum on semi-purified diets (AIN-76) containing (per kg) 400 (adequate), 200 (moderately restricted) or $20 \mathrm{mg}$ (severely restricted) $\mathrm{Mg}$ for $21 \mathrm{~d}$ while two groups were pair-fed the $\mathrm{Mg}$-adequate diet in the same quantities consumed by the groups fed on the moderately and severely $\mathrm{Mg}$-restricted diets respectively. Rats were housed individually in metabolism cages with a grid-floor and a facility for separate collection of faeces and urine. Feed was provided at 17.00 hours each day and all animals were given distilled water $a d$ libitum for the duration of the study. Rats were weighed weekly and examined daily for general condition and symptoms associated with $\mathrm{Mg}$ deficiency. Urine samples $(24 \mathrm{~h})$ were collected for each animal during the last $3 \mathrm{~d}$ of the study in vessels covered with aluminium foil to prevent degradation by light of the pyridinium crosslinks. The urine samples for each animal were pooled and the volumes
Table 1. Composition of the modified AIN-76 diet (American Institute of Nutrition, 1977)

\begin{tabular}{lc}
\hline Ingredient $^{\star}$ & Content $(\mathrm{g} / \mathrm{kg})$ \\
\hline Casein & 200.0 \\
DL-Methionine & 3.0 \\
Maize starch & 150.0 \\
Sucrose & 499.34 \\
Fibre & 50.0 \\
Maize oil & 50.0 \\
AIN mineral mix $\ddagger$ & 35.0 \\
AIN vitamin mix§ & 10.0 \\
Magnesium oxide & $0.66 \dagger$ \\
Choline bitartrate & 2.0 \\
\hline
\end{tabular}

* Sources of ingredients: casein (sodium caseinate, Kerrymore Milk Products Ltd, Listowel, Co. Kerry, Ireland); DL-methionine (Rhone Poulenc, Animal Nutrition, Commentry, France); maize starch (Cagill, Bergen op, Zoom, The Netherlands); sucrose (Irish Sugar plc, Sugar Division, Athy Road, Carlow, Ireland); fibre (Avicel microcrystalline cellulose, N.F., FMC International, Food and Pharmaceutical Products Division, Little Island, Cork, Ireland); maize oil (St Bernard's brand, Dunnes Stores Ltd, 67 Stephen Street, Upper Dublin 8, Ireland); choline bitartrate (Brown and Gilmore, Carrigaline East, Co. Cork, Ireland).

†Representing diet containing $400 \mathrm{mg} \mathrm{Mg} / \mathrm{kg}$; level of addition was reduced appropriately and replaced with sucrose for the moderately and severely Mgrestricted diets.

¥ Contained $(\mathrm{g} / \mathrm{kg})$ : potassium dihydrogen phosphate 376 , dipotassium hydrogen phosphate 160 , sodium chloride 74 , manganous carbonate 3.5 , ferric citrate 6 , zinc carbonate $1 \cdot 6$, cupric carbonate $0 \cdot 3$, potassium iodate 0.01 , sodium selenite 0.01 , chromium potassium sulfate 0.55 , sucrose 378 .

$\S$ Contained $(/ \mathrm{kg})$ : nicotinic acid $3 \mathrm{~g}$, calcium pantothenate $1.6 \mathrm{~g}$, riboflavin $600 \mathrm{mg}$, thiamin- $\mathrm{HCl} 600 \mathrm{mg}$, pyridoxine- $\mathrm{HCl} 700 \mathrm{mg}$, pteroylmonoglutamic acid $200 \mathrm{mg}$, biotin $20 \mathrm{mg}$, cyanocobalamin $1 \mathrm{mg}$, cholecalciferol $2.5 \mathrm{mg}$, menaquinone $5.0 \mathrm{mg}$, retinyl palmitate $120 \mathrm{mg}$, DL- $\alpha$ tocopheryl acetate $5000 \mathrm{mg}$

recorded. Portions of the pooled urine samples were acidified with $12 \mathrm{M}-\mathrm{HCl}(225 \mu \mathrm{l} / 100 \mathrm{ml}$ urine $)$ and stored at $-20^{\circ}$ until required for analysis.

After $21 \mathrm{~d}$ on the respective diets, all animals were anaesthetized with diethyl ether and blood was drawn from the heart into vacutainer tubes, processed to serum, and immediately stored at $-70^{\circ}$ until required. Final body weights were recorded and femora, livers and kidneys (from the right side of each animal) were harvested. Kidneys and livers were cleaned of adhering tissue, weighed and stored at $-20^{\circ}$ until required for mineral analysis. Femora were cleaned of adhering soft tissue, the distal epiphyses removed, and the metaphyses were freed of bone marrow and blood. The left femoral metaphyses were immediately placed in aluminium foil and immersed in liquid $\mathrm{N}_{2}$ and were subsequently stored at $-80^{\circ}$ until required for mRNA analysis. The right femoral metaphyses were dried overnight at $110^{\circ}$, weighed and stored in sealed containers until required for mineral analysis.

\section{Experimental techniques}

Urinary pyridinoline and deoxypyridinoline. Pooled urine samples for each animal were analysed in duplicate using a three-step procedure. Urine was first hydrolysed with an equal volume of $12 \mathrm{M}-\mathrm{HCl}$ at $110^{\circ}$ for $18 \mathrm{~h}$, the crosslinks were then extracted by $\mathrm{CF} 1$ cellulose chromatography with the use of an internal standard (acetylated pyridinoline, MetraBiosystems Ltd, Wheatley, Oxon., UK) and were measured using a reversed-phase HPLC method with fluorescence detection (Colwell et al. 1993). The acetylated 
pyridinoline was used in accordance with the method as described by Calabresi et al. (1994) and Robins et al. (1994). The crosslinks contents of urine samples were quantitated by external standardization using a commercially available pyridinoline (Pyr)-deoxypyridinoline (Dpyr) HPLC calibrator (MetraBiosystems Ltd). The intra-assay CV for Pyr and Dpyr measured as the variation between ten chromatograms obtained between column regenerations as described by Colwell et al. (1993) were $6 \%$ and $9 \%$ respectively. The inter-assay $\mathrm{CV}$ for Pyr and Dpyr were $7 \%$ and $9 \%$ respectively.

Femoral phosphorus and femoral, liver, kidney and urinary calcium and magnesium levels. Weighed femoral metaphyses (dried), kidneys and portions (about $1 \mathrm{~g}$ ) from each liver were digested in $10 \mathrm{ml}$ of $16 \mathrm{M}-\mathrm{HNO}_{3}-12 \mathrm{M}-\mathrm{HClO}_{4}$ $(2: 1, \mathrm{v} / \mathrm{v})$ on a hot plate (S \& J Juniper \& Co., Harlow, Essex, UK) until the sample colour resembled that of the reagent blank. $\mathrm{Ca}$ and $\mathrm{Mg}$ were analysed in duplicate in femoral, kidney and liver digests and in urine by atomic absorption spectrophotometry (Pye-Unicam Atomic Absorption Spectrophotometer, Model SP9; Pye Unicam, Cambridge, Cambs., UK) after appropriate dilution with $\mathrm{LaCl}_{3}$ solution ( $5 \mathrm{~g} / \mathrm{l}, \mathrm{BDH} \mathrm{Ltd}$, Poole, Dorset, UK). A range of $\mathrm{Ca}$ and $\mathrm{Mg}$ standards was used to obtain $\mathrm{Ca}$ and $\mathrm{Mg}$ calibration curves. The intra- and inter-assay $\mathrm{CV}$ for $\mathrm{Ca}$ were $2.8 \%$ and $7.8 \%$, and for $\mathrm{Mg}$ were $3.2 \%$ and $8.8 \%$ respectively. $\mathrm{P}$ was determined in the femoral digests by the method of Weissman \& Pileggi (1974). The intra- and inter-assay CV for P were $4.2 \%$ and $6.1 \%$ respectively.

Serum calcium and magnesium. Both $\mathrm{Ca}$ and $\mathrm{Mg}$ were analysed in duplicate in serum samples according to previously described methods (Trudeau \& Freier, 1967; Pesce \& Kaplan, 1987). The intra- and inter-assay CV for Ca were $3.1 \%$ and $5.6 \%$, and for $\mathrm{Mg}$ were $2.8 \%$ and $4.2 \%$ respectively.

Serum osteocalcin. Serum osteocalcin concentrations were measured in duplicate using a recently developed ELISA (Biomedical Technologies Inc., Stoughton, MA, USA). The intra- and inter-assay CV were 4.0 and $6.2 \%$ respectively.

Reverse transcription polymerase chain reaction analysis for femoral osteocalcin mRNA. RNA was isolated and analysed in the left femoral metaphysis from each rat within a group ( $n$ 8) as described previously (Fleet \& Hock, 1994). Four pooled total RNA samples from each group were prepared by combining portions of RNA from pairs of animals within a group and $1 \mu \mathrm{g}$ of each pooled total RNA sample was made into cDNA by a reverse transcription reaction as described by Fleet \& Hock (1994). The cDNA solution (containing $0.1 \mu \mathrm{g}$ equivalent RNA) was then amplified by polymerase chain reaction (PCR) for twentyfive cycles for both osteocalcin and glyceraldehyde phosphate dehydrogenase (EC 1.2.1.12) as described by Fleet \& Hock (1994). A PCR blank consisting of PCR reaction cocktail and water in place of the RNA sample was included during each amplification; under no circumstance did PCR product bands appear in these control samples. PCR products were electrophoretically run on $20 \mathrm{~g} / \mathrm{l}$ agarose gels containing ethidium bromide. Gels were visualized under u.v. light and photographed. Following electrophoresis, a ratio between the two PCR products (i.e. osteocalcin: glyceraldehyde phosphate dehydrogenase) within a cDNA sample was then determined by densitometry. The ratios between the two PCR products in the five dietary groups were compared statistically and the mean ratios in the Mg-restricted groups were expressed as a percentage of the ratios obtained in the respective pair-fed control groups (which were arbitrarily set at $100 \%$ ).

\section{Statistical methods}

Data are presented as means with their standard errors. All data were subjected to one-way ANOVA, with variation attributed to dietary Mg (Snedecor \& Cochran, 1967). To follow up the ANOVA, all pairs of means were compared by the method of least significant difference (Snedecor \& Cochran, 1967).

\section{Results}

Dietary restriction of $\mathrm{Mg}$ to 200 and $20 \mathrm{mg} / \mathrm{kg}$ led to reduced food intake which was more marked for the group fed on the diet containing $20 \mathrm{mg} \mathrm{Mg} / \mathrm{kg}$ (Table 2). This resulted in a slower growth rate which was significant by week 2 in the severely restricted group and by week 3 in the moderately restricted group (Fig. 1). However, weight gain and food conversion efficiency of the $\mathrm{Mg}$-restricted groups were similar to those of the corresponding controls which were pair-fed with the $\mathrm{Mg}$-adequate $(400 \mathrm{mg} / \mathrm{kg}$ ) diet (Table 2).

The rats in the severely restricted group had visible skin sores and were more irritable than rats in the corresponding pair-fed group by day 7 of the study. The rats in the moderately restricted group did not present with these visible symptoms of $\mathrm{Mg}$ deficiency at any stage of the study.

The influence of dietary $\mathrm{Mg}$ concentration on kidney and liver $\mathrm{Ca}$ and $\mathrm{Mg}$ concentrations is shown in Table 3. Severe, but not moderate, dietary $\mathrm{Mg}$ restriction increased $\mathrm{Ca}$ concentration and reduced $\mathrm{Mg}$ concentration in the kidney. Neither liver Ca nor $\mathrm{Mg}$ concentration was affected by the restriction of dietary $\mathrm{Mg}$.

Serum $\mathrm{Mg}$ concentration was greatly reduced (compared with the corresponding pair-fed controls) in the group fed on the severely restricted diet $(20 \mathrm{mg} \mathrm{Mg} / \mathrm{kg}$ ) but was unaffected in the group fed on the moderately restricted diet $(200 \mathrm{mg} \mathrm{Mg} / \mathrm{kg}$ ) (Table 4). Serum $\mathrm{Mg}$ level was unaffected by the restricted intake of the Mg-adequate diet in the pair-fed control groups compared with the ad libitumfed Mg-adequate group.

Urinary Pyr and Dpyr and serum osteocalcin levels were significantly reduced (compared with the corresponding pair-fed controls) in both the severely restricted group and the moderately restricted group (Table 4). For serum osteocalcin, but not urinary Pyr or Dpyr, the reduction was more marked in the severely restricted group than in the moderately restricted group. However, these markers were unaffected by the restricted intake of the Mg-adequate diet in the pair-fed control groups compared with the ad libitum-fed $\mathrm{Mg}$-adequate group.

Expression of the osteocalcin gene in the femurs of the severely restricted and moderately restricted groups was down-regulated compared with that in the corresponding 
Table 2. Effect of moderately and severely restricted dietary magnesium intakes on food intake, weight gain and food conversion efficiency in young male rats*

(Mean values with their standard errors)

\begin{tabular}{|c|c|c|c|c|c|c|c|c|}
\hline \multirow[b]{2}{*}{ Group } & \multirow{2}{*}{$\begin{array}{l}\text { Dietary Mg } \\
(\mathrm{mg} / \mathrm{kg})\end{array}$} & \multirow[b]{2}{*}{$n$} & \multicolumn{2}{|c|}{$\begin{array}{l}\text { Food intake } \\
\text { (g/21 d) }\end{array}$} & \multicolumn{2}{|c|}{$\begin{array}{l}\text { Weight gain } \\
(\mathrm{g} / 21 \mathrm{~d})\end{array}$} & \multicolumn{2}{|c|}{$\begin{array}{l}\text { Food conversion } \\
\text { efficiency }\end{array}$} \\
\hline & & & Mean & SE & Mean & SE & Mean & SE \\
\hline $\begin{array}{l}\text { Severely Mg-deficient } \\
\text { Severely Mg-deficient, PF }\end{array}$ & $\begin{array}{r}20 \\
400\end{array}$ & $\begin{array}{l}8 \\
8\end{array}$ & $\begin{array}{l}198^{\mathrm{C}} \\
204^{\mathrm{C}}\end{array}$ & $\begin{array}{l}4 \\
5\end{array}$ & $\begin{array}{l}46 \cdot 7^{\mathrm{c}} \\
48 \cdot 9^{\mathrm{c}}\end{array}$ & $\begin{array}{l}5 \cdot 1 \\
5 \cdot 2\end{array}$ & $\begin{array}{l}0.23^{b} \\
0.24^{b}\end{array}$ & $\begin{array}{l}0.02 \\
0.02\end{array}$ \\
\hline $\begin{array}{l}\text { Moderately Mg-deficient } \\
\text { Moderately Mg-deficient, PF }\end{array}$ & $\begin{array}{l}200 \\
400\end{array}$ & $\begin{array}{l}8 \\
8\end{array}$ & $\begin{array}{l}269^{b} \\
269^{b}\end{array}$ & $\begin{array}{l}3 \\
3\end{array}$ & $\begin{array}{l}86 \cdot 2^{\mathrm{b}} \\
86 \cdot 6^{\mathrm{b}}\end{array}$ & $\begin{array}{l}6 \cdot 0 \\
7 \cdot 1\end{array}$ & $\begin{array}{l}0.32^{\mathrm{a}} \\
0.32^{\mathrm{a}}\end{array}$ & $\begin{array}{l}0.02 \\
0.02\end{array}$ \\
\hline Adequate $\mathrm{Mg}$ & 400 & 8 & $310^{a}$ & 3 & $105 \cdot 8^{\mathrm{a}}$ & $7 \cdot 6$ & $0.34^{a}$ & 0.02 \\
\hline ANOVA (one-way), $P$ value & & & \multicolumn{2}{|c|}{$<0.001$} & \multicolumn{2}{|c|}{$<0.001$} & \multicolumn{2}{|c|}{$<0.001$} \\
\hline
\end{tabular}

$\mathrm{PF}$, pair-fed to the corresponding Mg-deficient group.

a,b,c Mean values within a column with different superscript letters were significantly different, $P<0.05$ (ANOVA followed by least significant difference test).

${ }^{*}$ For details of diets and procedures, see Table 1 and pp. 64-65.

†Calculated as weight gain $(\mathrm{g}) /$ food intake $(\mathrm{g})$ over $21 \mathrm{~d}$.

pair-fed control groups (Fig. 2). This was more marked in the severely restricted group ( $46 \%$ reduction) than in the moderately restricted group ( $22 \%$ reduction). Expression of the osteocalcin gene was unaffected by the restricted intake of the Mg-adequate diet in the pair-fed control groups compared with the ad libitum-fed $\mathrm{Mg}$-adequate group.

Femoral dry weight was reduced in the severely restricted group, but not in the moderately restricted group, compared with the corresponding pair-fed control groups (Table 5). However, femoral dry weights were unaffected by the restricted intake of the $\mathrm{Mg}$-adequate diet in the pair-fed control groups compared with the ad libitum-fed $\mathrm{Mg}$-adequate group.

Femoral $\mathrm{Mg}$ concentration was reduced in both the severely restricted and moderately restricted groups compared with the pair-fed controls and this was more marked for the severely restricted group (Table 5). However, femoral $\mathrm{Mg}$ was unaffected by the restricted intake of the $\mathrm{Mg}$-adequate diet in the pair-fed groups compared with the ad libitum-fed $\mathrm{Mg}$-adequate group. Neither femoral $\mathrm{Ca}$ nor

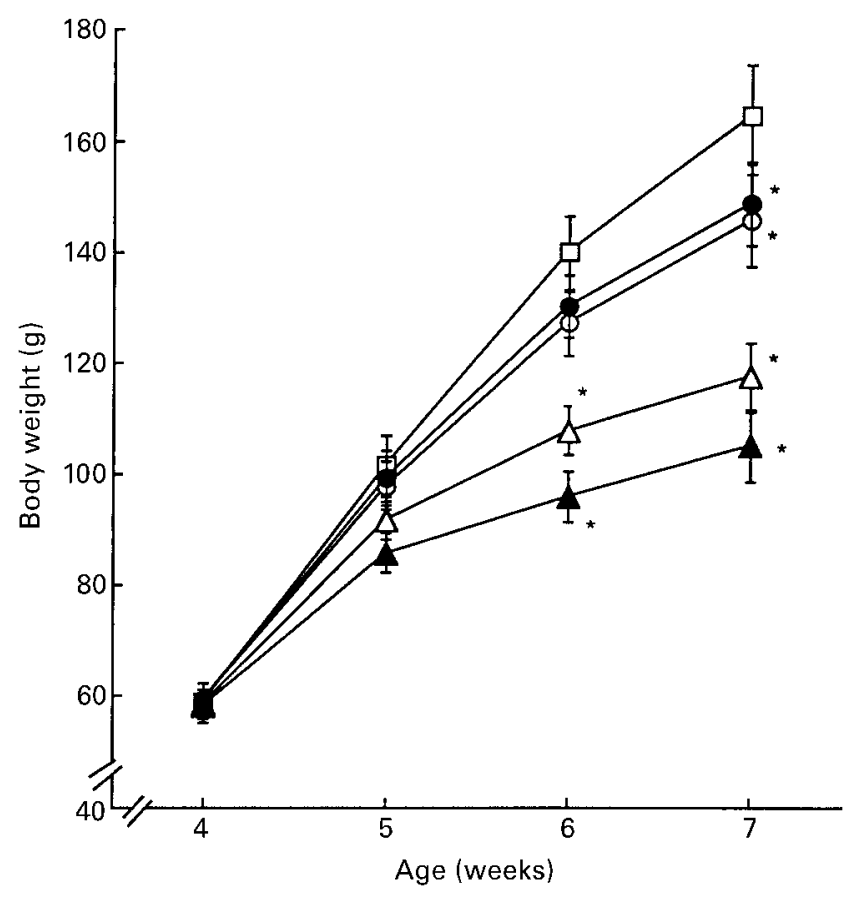

Fig. 1. Body weights over time in rats fed on diets containing different levels of magnesium. Groups were: ( $\square$ ), adequate magnesium diet; ( $\bullet$ ), moderately magnesium-deficient diet; $(\bigcirc)$, adequate magnesium diet but pair-fed to the moderately deficient group; ( $\mathbf{\Lambda})$, severely magnesiumdeficient diet; $(\triangle)$, adequate magnesium diet but pair-fed to the severely-deficient group. Values are means for eight rats, with their standard errors represented by vertical bars. Mean values were significantly different from those of the adequate magnesium group: ${ }^{*} P<0.05$ (ANOVA followed by least significant difference test). For details of diets, see Table 1. 
Table 3. Effect of moderately and severely restricted dietary magnesium intakes on concentrations of calcium and magnesium in kidney and liver in young male rats*

(Mean values with their standard errors)

\begin{tabular}{|c|c|c|c|c|c|c|c|c|c|c|}
\hline \multirow[b]{3}{*}{ Group } & \multirow{3}{*}{$\begin{array}{l}\text { Dietary Mg } \\
(\mathrm{mg} / \mathrm{kg})\end{array}$} & \multirow[b]{3}{*}{$n$} & \multicolumn{4}{|c|}{ Kidney } & \multicolumn{4}{|c|}{ Liver } \\
\hline & & & \multicolumn{2}{|c|}{$\mathrm{Ca}(\mu \mathrm{g} / \mathrm{g}) \dagger$} & \multicolumn{2}{|c|}{$M g(\mu g / g) \dagger$} & \multicolumn{2}{|c|}{$\mathrm{Ca}(\mu \mathrm{g} / \mathrm{g}) \dagger$} & \multicolumn{2}{|c|}{$M g(\mu g / g) \dagger$} \\
\hline & & & Mean & SE & Mean & SE & Mean & SE & Mean & SE \\
\hline $\begin{array}{l}\text { Severely Mg-deficient } \\
\text { Severely Mg-deficient, PF }\end{array}$ & $\begin{array}{r}20 \\
400\end{array}$ & $\begin{array}{l}8 \\
8\end{array}$ & $\begin{array}{l}482^{\mathrm{b}} \\
122^{\mathrm{a}}\end{array}$ & $\begin{array}{l}16 \\
16\end{array}$ & $\begin{array}{l}154^{\mathrm{b}} \\
166^{\mathrm{a}}\end{array}$ & $\begin{array}{l}1 \\
3\end{array}$ & $\begin{array}{l}83 \cdot 2^{\mathrm{a}} \\
82 \cdot 0^{\mathrm{a}}\end{array}$ & $\begin{array}{l}3 \cdot 1 \\
4 \cdot 6\end{array}$ & $\begin{array}{l}171^{\mathrm{a}} \\
175^{\mathrm{a}}\end{array}$ & $\begin{array}{l}5 \\
2\end{array}$ \\
\hline $\begin{array}{l}\text { Moderately Mg-deficient } \\
\text { Moderately Mg-deficient, PF }\end{array}$ & $\begin{array}{l}200 \\
400\end{array}$ & $\begin{array}{l}8 \\
8\end{array}$ & $\begin{array}{l}103^{\mathrm{a}} \\
103^{\mathrm{a}}\end{array}$ & $\begin{array}{r}9 \\
11\end{array}$ & $\begin{array}{l}167^{\mathrm{a}} \\
171^{\mathrm{a}}\end{array}$ & $\begin{array}{l}4 \\
4\end{array}$ & $\begin{array}{l}73 \cdot 2^{\mathrm{a}} \\
80 \cdot 8^{\mathrm{a}}\end{array}$ & $\begin{array}{l}4 \cdot 2 \\
4 \cdot 8\end{array}$ & $\begin{array}{l}160^{\mathrm{a}} \\
166^{\mathrm{a}}\end{array}$ & $\begin{array}{l}5 \\
4\end{array}$ \\
\hline Adequate $\mathrm{Mg}$ & 400 & 8 & $97^{\mathrm{a}}$ & 6 & $170^{\mathrm{a}}$ & 3 & $88.9^{a}$ & 4.9 & $169^{\mathrm{a}}$ & 3 \\
\hline ANOVA (one-way), $P$ value & & & \multicolumn{2}{|c|}{$<0.001$} & \multicolumn{2}{|c|}{$<0.01$} & \multicolumn{2}{|c|}{0.20} & \multicolumn{2}{|c|}{0.35} \\
\hline
\end{tabular}

$\mathrm{PF}$, pair-fed to the corresponding Mg-deficient group.

a,b Mean values within a column with different superscript letters were significantly different, $P<0.05$ (ANOVA followed by least significant difference test).

*For details of diets and procedures, see Table 1 and pp. 64-65.

†Expressed on a wet weight basis.

$\mathrm{P}$ concentration was affected by the restriction of dietary $\mathrm{Mg}$ (Table 5).

\section{Discussion}

It is well established that in an experiment in which food is given ad libitum the animals on a Mg-deficient diet reduce their food intake and the control animals consume far more. This can cause difficulties in attributing changes in animals entirely to $\mathrm{Mg}$ intake, as there will be multiple nutritional deficiencies as a result of reduced food consumption. The present study used a pair-feeding paradigm and therefore the differences and similarities in bone-related variables between animals of the Mg-restricted groups and those of the respective pair-fed control groups are emphasized as valid comparisons attributable to $\mathrm{Mg}$ intake alone.

In the present study, moderate dietary restriction of $\mathrm{Mg}$ ( $200 \mathrm{mg} / \mathrm{kg}$ diet) reduced femur $\mathrm{Mg}$ concentration, but had no effect on the $\mathrm{Mg}$ concentration in serum, kidney or liver, suggesting that bone is particularly sensitive to dietary $\mathrm{Mg}$ restriction. This is in agreement with the findings of other studies which have examined the effect of moderate $\mathrm{Mg}$ deprivation on femoral $\mathrm{Mg}$ concentration in the rat (Héroux et al. 1975; Lerma et al. 1993). Similarly, severe dietary restriction of $\mathrm{Mg}(20 \mathrm{mg} / \mathrm{kg}$ diet $)$ greatly reduced rat femur $\mathrm{Mg}$ concentration in the present study. This is in agreement with other studies which have examined the influence of severe dietary $\mathrm{Mg}$ deprivation on femoral $\mathrm{Mg}$ concentration (Jones et al. 1980; Welsh \& Weaver, 1988; Kenney et al. 1994; Vormann et al. 1997).

Bone has been suggested as being one of the tissues most affected by Mg deficiency as it is one of the major storage sites for Mg in the body (Anast \& Gardener, 1981; Wallach, 1990). $\mathrm{Mg}$ in bone is found mainly either absorbed on the surface of the apatite crystallites or in the crystal lattice where it replaces Ca (Dallemagne \& Fabry, 1956; Alfrey et al. 1974). The surface-limited $\mathrm{Mg}$ in bone is readily exchangeable and rapidly available during $\mathrm{Mg}$ depletion (Neuman \& Mulryan, 1971). It has been reported that rat femur containing a normal concentration of $\mathrm{Ca}$ but a

Table 4. Effect of moderately and severely restricted dietary magnesium intakes on serum calcium, magnesium and osteocalcin levels and urinary pyridinoline (Pyr) and deoxypyridinoline (Dpyr) concentrations in young male rats ${ }^{*}$

(Mean values with their standard errors)

\begin{tabular}{|c|c|c|c|c|c|c|c|c|c|c|c|c|}
\hline \multirow{2}{*}{ Group } & \multirow{2}{*}{$\begin{array}{c}\text { Dietary Mg } \\
(\mathrm{mg} / \mathrm{kg})\end{array}$} & \multirow{2}{*}{$n$} & \multicolumn{6}{|c|}{ Serum } & \multicolumn{4}{|c|}{ Urine } \\
\hline & & & \multicolumn{2}{|c|}{$\begin{array}{c}\mathrm{Ca} \\
(\mathrm{mg} / \mathrm{l})\end{array}$} & \multicolumn{2}{|c|}{$\underset{(\mathrm{mg} / \mathrm{l})}{\mathrm{Mg}}$} & \multicolumn{2}{|c|}{$\begin{array}{l}\text { Osteocalcin } \\
(\mu \mathrm{g} / \mathrm{l})\end{array}$} & \multicolumn{2}{|c|}{$\begin{array}{c}\text { Pyr } \\
(\mathrm{nmol} / \mathrm{d})\end{array}$} & \multicolumn{2}{|c|}{$\begin{array}{c}\text { Dpyr } \\
\text { (nmol/d) }\end{array}$} \\
\hline $\begin{array}{l}\text { Severely Mg-deficient } \\
\text { Severely Mg-deficient, PF }\end{array}$ & $\begin{array}{r}20 \\
400\end{array}$ & $\begin{array}{l}8 \\
8\end{array}$ & $\begin{array}{l}124^{a} \\
108^{a}\end{array}$ & $\begin{array}{l}4 \\
5\end{array}$ & $\begin{array}{r}7 \cdot 3^{b} \\
23 \cdot 9^{a}\end{array}$ & $\begin{array}{l}0.4 \\
1.2\end{array}$ & $\begin{array}{l}46 \cdot 9^{c} \\
87 \cdot 4^{a}\end{array}$ & $\begin{array}{l}3 \cdot 7 \\
7 \cdot 4\end{array}$ & $\begin{array}{l}12 \cdot 7^{\mathrm{b}} \\
22 \cdot 8^{\mathrm{a}}\end{array}$ & $\begin{array}{l}1 \cdot 7 \\
2 \cdot 5\end{array}$ & $\begin{array}{l}17 \cdot 7^{\mathrm{b}} \\
29 \cdot 4^{\mathrm{a}}\end{array}$ & $\begin{array}{l}3.4 \\
3.2\end{array}$ \\
\hline Adequate $\mathrm{Mg}$ & 400 & 8 & $116^{\mathrm{a}}$ & 7 & $25 \cdot 8^{\mathrm{a}}$ & 1.4 & $93 \cdot 6^{a}$ & 7.4 & $27 \cdot 8^{a}$ & 1.8 & $37 \cdot 5^{\mathrm{a}}$ & $3 \cdot 7$ \\
\hline ANOVA (one-way), $P$ value & & & \multicolumn{2}{|c|}{0.14} & \multicolumn{2}{|c|}{$<0.001$} & \multicolumn{2}{|c|}{$<0.001$} & \multicolumn{2}{|c|}{$<0.001$} & \multicolumn{2}{|c|}{$<0.001$} \\
\hline
\end{tabular}

PF, pair-fed to the corresponding Mg-deficient group.

a,b,c Mean values within a column with different superscript letters were significantly different, $P<0.05$ (ANOVA followed by least significant difference test).

* For details of diets and procedures, see Table 1 and pp. 64-65. 
(A)
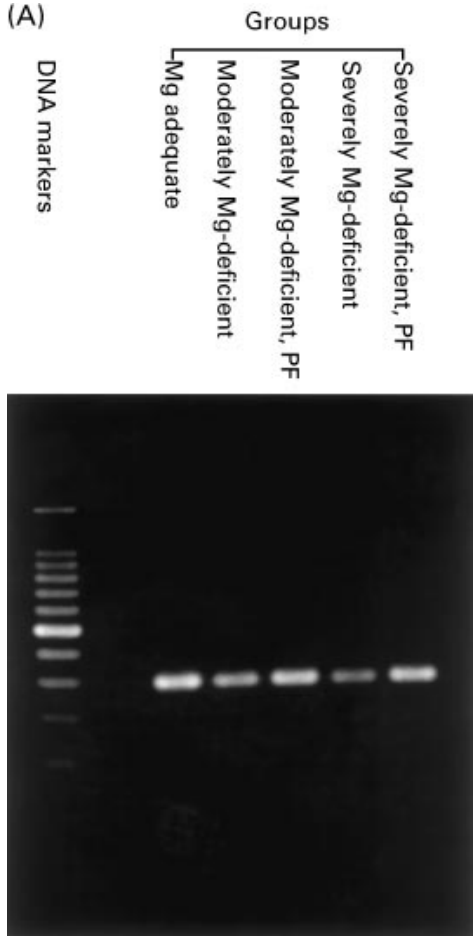

(B)
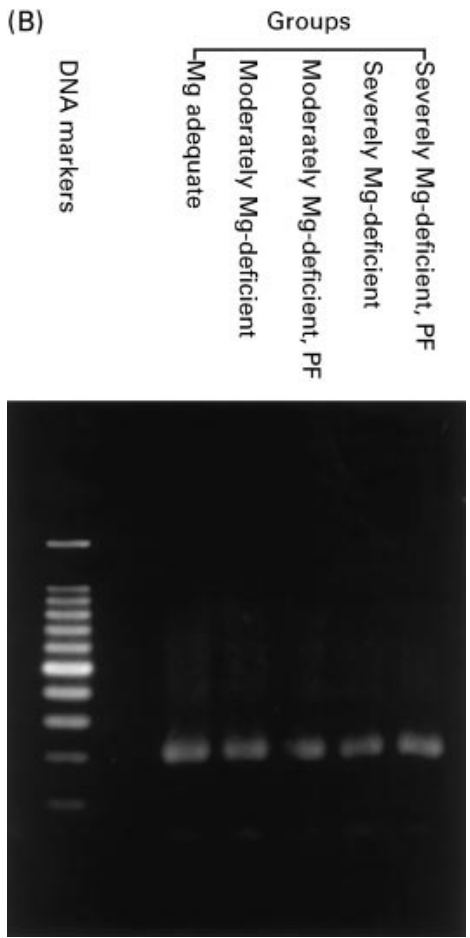

Fig. 2. (A) Osteocalcin mRNA and (B) glyceraldehyde phosphate dehydrogenase (GADPH) mRNA levels in the femurs of rats fed on severely magnesium-deficient, moderately magnesium-deficient or magnesium-adequate diets, or pair-fed (PF) with the magnesium-adequate diet to the magnesium-deficient groups. Total RNA was isolated from the femoral metaphyses of rats $(n 8)$ in each of the five dietary groups. cDNA was prepared from total pooled RNA and subsequently analysed for osteocalcin and GADPH mRNA by reverse transcription polymerase chain reaction using twenty-five cycles of amplification (for details, see p. 65). DNA size markers: 1500, 1000, 900, 800, 700, 600, 500, 400, 300, 200 and 100 base pairs from top to bottom. Osteocalcin and GADPH polymerase chain reaction product sizes were 293 and 194 base pairs respectively.

reduced $\mathrm{Mg}$ concentration had significantly reduced strength (Kenney et al. 1994).

In the present study, moderate $\mathrm{Mg}$ restriction $(200 \mathrm{mg} / \mathrm{kg}$ diet) had no effect on femur dry weight. In contrast, severe $\mathrm{Mg}$ restriction $(20 \mathrm{mg} / \mathrm{kg}$ diet) reduced femur dry weight. This is in agreement with the findings of Kenney et al. (1994) which showed that rats receiving $50 \mathrm{mg} \mathrm{Mg} / \mathrm{kg}$ diet for 32-42 d had lower femoral dry weights compared with animals receiving adequate $\mathrm{Mg}$ intakes $(500 \mathrm{mg} \mathrm{Mg} / \mathrm{kg}$ diet). In the present study, neither moderate nor severe $\mathrm{Mg}$ restriction affected the $\mathrm{Ca}$ or $\mathrm{P}$ content of femur. This is in agreement with the findings of other studies which examined the influence of dietary $\mathrm{Mg}$ deprivation on femoral concentration of Ca (Héroux et al. 1975; Jones et al. 1980;

Table 5. Effect of moderately and severely restricted dietary magnesium intakes on femur dry weight and concentrations of calcium, magnesium and phosphorus in young male rats*

(Mean values with their standard errors)

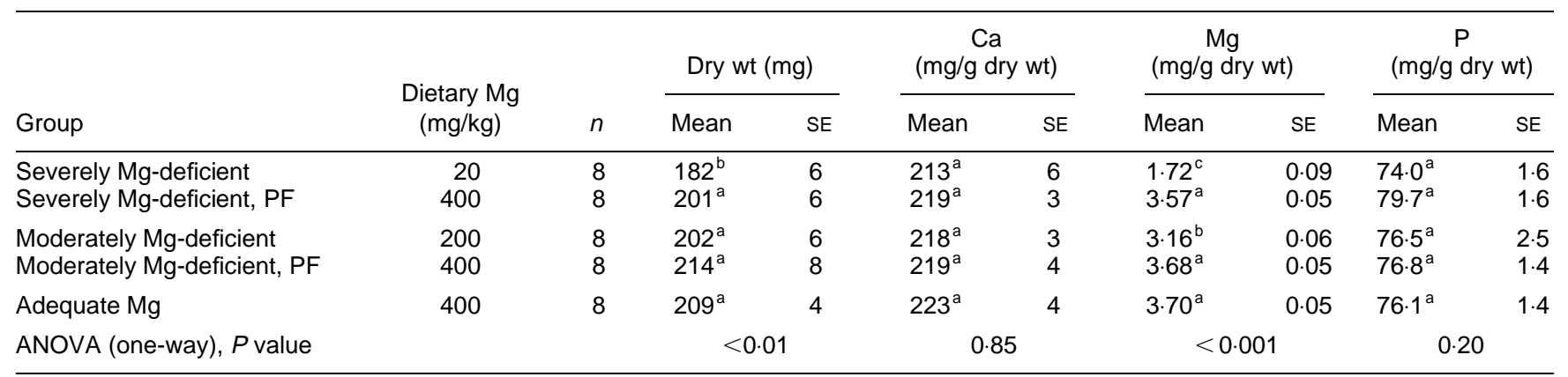

$\mathrm{PF}$, pair-fed to the corresponding Mg-deficient group.

a,b,c Mean values within a column with different superscript letters were significantly different, $P<0.05$ (ANOVA followed by least significant difference test).

${ }^{*}$ For details of diets and procedures, see Table 1 and pp. 64-65. 
Boskey et al. 1992; Kenney et al. 1994) and P (Welsh \& Weaver, 1988; Kimura \& Itokawa, 1989) in rats.

Both moderate and severe dietary restriction of $\mathrm{Mg}$ lowered serum levels of osteocalcin, a marker of bone formation. The reduction in serum osteocalcin, however, was much less marked in moderately restricted rats $(28 \%)$ than in severely restricted rats $(54 \%)$. These findings are in agreement with the findings of Carpenter et al. (1992) which showed that severe $\mathrm{Mg}$ deficiency (feeding $20 \mathrm{mg} \mathrm{Mg} / \mathrm{kg}$ diet for $12 \mathrm{~d}$ ) in young growing rats led to $38 \%$ lower serum osteocalcin levels compared with that of $\mathrm{Mg}$-replete animals (400 mg Mg/kg diet). Furthermore, Carpenter et al. (1992) showed that the effect of $\mathrm{Mg}$ deprivation on osteocalcin occurred relatively rapidly as significant differences were apparent $2 \mathrm{~d}$ after implementation of the $\mathrm{Mg}$-deficient diet and preceded changes in parathyroid hormone, 1,25dihydroxyvitamin $\mathrm{D}$, or serum $\mathrm{Ca}$, supporting the notion that $\mathrm{Mg}$ deprivation has a direct effect on the osteoblast. Boskey et al. (1992) found that the osteocalcin content of the metaphyseal bone of severely Mg-deficient animals (fed with $20 \mathrm{mg} \mathrm{Mg} / \mathrm{kg}$ diet for $17 \mathrm{~d}$ ) was significantly less than that of $\mathrm{Mg}$-replete animals (fed with $650 \mathrm{mg} \mathrm{Mg} / \mathrm{kg}$ diet). Alkaline phosphatase (EC 3.1.3.1) activity, another biochemical marker of bone formation, has also been reported to be reduced in bone (Heaton, 1965; Elin, 1969; Lai et al. 1975) and serum (Synder \& Tweedy, 1942; Heaton, 1965; Elin, 1969) in severely $\mathrm{Mg}$-deficient rats. The effect of moderate $\mathrm{Mg}$ restriction on serum osteocalcin or on other markers of bone formation in the rat has not been reported elsewhere in the literature.

In the present study there was a reduced expression of osteocalcin mRNA in femora of both moderately and severely Mg-restricted animals compared with the corresponding pair-fed control groups which seemed to be doserelated and were consistent with the serum findings. Reduced expression of osteocalcin mRNA in osteoblasts in rat calvaria has also been demonstrated by Carpenter et al. (1992) but only in severe Mg deficiency. Although an effect on the osteocalcin secretory process cannot be excluded, this evidence suggests that the regulation of osteocalcin synthesis is altered at the transcriptional level during $\mathrm{Mg}$ deprivation and that this, at least in part, accounts for the changes described in the circulating levels of the protein. The role of osteocalcin in bone is unclear. Until recently, osteocalcin was believed to have a positive role in bone mineralization, as it has a very strong ability to bind hydroxyapatite (Power \& Fottrell, 1991); however, recent evidence from osteocalcin gene knockout studies indicates that it may act as a negative regulator of bone formation (Ducy et al. 1996). Therefore, it is unclear if the reduced synthesis of osteocalcin resulting from $\mathrm{Mg}$ deprivation (both moderate and severe) in the present study adversely affected the mineralization process or whether it merely reflected either reduced osteoblast numbers or reduced osteoblastic activity or both, as suggested by Robins \& New (1997). Reduced osteoblast numbers and reduced osteoblastic activity have been suggested to have a role, at least in part, in the decreased rate of bone formation observed in Mg-deficient rats (Jones et al. 1980; Carpenter et al. 1992).

Both moderate and severe dietary restriction of $\mathrm{Mg}$ reduced the rate of bone resorption in the present study, as measured by the urinary excretion of pyridinium crosslinks which are regarded as specific markers of bone resorption in rats (Black et al. 1989; Egger et al. 1994). This is in agreement with the findings of earlier studies which reported reduced excretion of urinary hydroxyproline in severe $\mathrm{Mg}$ deficiency in young rats (MacManus \& Heaton, 1969; Rayssiguier \& Larvor, 1978). In addition, the release of ${ }^{45} \mathrm{Ca}$ from labelled rat bone, both in vitro and in vivo (an index of bone resorption), has also been shown to be reduced by severe $\mathrm{Mg}$ deficiency (MacManus \& Heaton, 1969; Larvor \& Labat, 1978). The effect of moderate $\mathrm{Mg}$ restriction on the rate of bone resorption in the rat has not been reported elsewhere in the literature. It was notable that in the present study moderate restriction of $\mathrm{Mg}$ intake reduced the excretion of the pyridinium crosslinks to the same degree as did severe $\mathrm{Mg}$ restriction.

The mechanism by which $\mathrm{Mg}$ deficiency caused a reduction in the rate of bone resorption remains unclear. One possible explanation is that it could be due to a reduction in serum parathyroid hormone levels, common in $\mathrm{Mg}$-deficient rats (Rayssiguier et al. 1982; Anast \& Forte, 1983). An alternative explanation may be a reduced sensitivity to parathyroid hormone of $\mathrm{Mg}$-deficient bone, as suggested by some researchers (MacManus et al. 1971; Rayssiguier \& Larvor, 1978; Jones et al. 1980). However, Kenney et al. (1994) have argued against this since it has been shown that infusion of parathyroid hormone into parathyroidectomized, Mg-deficient rats brings about expected responses of bone (Hahn et al. 1972).

In addition to its effects on bone composition and bone metabolism in the present study, dietary $\mathrm{Mg}$ restriction produced several other characteristic signs of $\mathrm{Mg}$ depletion. For example, animals fed on the severely $\mathrm{Mg}$-restricted diet $(20 \mathrm{mg} / \mathrm{kg} \mathrm{diet})$ showed signs that are characteristic of gross $\mathrm{Mg}$ deficiency, including skin sores and irritability, and reduced food intake with consequent reduced weight gain (Walser, 1967; Jones et al. 1980; Lerma et al. 1993; Kimura et al. 1996). Furthermore, Mg concentration was reduced in serum and kidney as well as in femur, indicative of body $\mathrm{Mg}$ depletion. These findings are in agreement with those of many other studies on severe dietary restriction of $\mathrm{Mg}$ (Lai et al. 1975; Jones et al. 1980; Boskey et al. 1992; Kenney et al. 1994; Kimura et al. 1996; Vormann et al. 1997). In addition, there was an increased concentration of $\mathrm{Ca}$ in kidneys, a well-established sign of severe $\mathrm{Mg}$ deficiency which is believed to be due to the formation of calcium phosphate and calcium oxalate in renal tubules (Bunce \& King, 1978; Koh et al. 1989). Moderate dietary restriction of $\mathrm{Mg}(200 \mathrm{mg} / \mathrm{kg}$ diet $)$ also resulted in signs of $\mathrm{Mg}$ deficiency, i.e. reduced food intake and weight gain, although these were much less marked than for the severely restricted group.

In conclusion, the findings of the present study suggest that not only severe but also moderate dietary restriction of $\mathrm{Mg}$ over $21 \mathrm{~d}$ resulted in qualitative changes in bone (i.e. reduced $\mathrm{Mg}$ concentrations) as well as in aberrant bone turnover in young growing rats (i.e. severely depressed rates of bone formation and bone resorption). Aberrant bone turnover could impair bone development and reduced $\mathrm{Mg}$ concentration in bone may have implications for bone 
strength and increased risk of bone fragility (Kenney et al. 1994). These effects of moderate $\mathrm{Mg}$ restriction in rats may be of relevance to human populations in Western countries where it has been shown that many individuals have intakes of $\mathrm{Mg}$ which are significantly below the recommended levels (Gregory et al. 1990; Van Dokkum, 1995; Cleveland et al. 1996). Therefore, the evidence given here together with data from epidemiological studies which suggest a link between low Mg intake and osteoporosis (see reviews by Sojka \& Weaver, 1995; Institute of Medicine, 1997; Rude, 1998) indicate a need for investigation of the role of $\mathrm{Mg}$ in bone metabolism in man.

\section{Acknowledgement}

This research has been part-funded by grant aid under the Food Sub-Programme of the Operational Programme for Industrial Development which is administered by the Department of Agriculture, Food and Forestry, Dublin, and supported by national and European Union funds.

\section{References}

Alfrey AC, Miller NL \& Trow R (1974) Effect of age and magnesium depletion on bone magnesium pools in rats. Journal of Clinical Investigation 54, 1074-1081.

American Institute of Nutrition (1977) Report of the American Institute ad hoc committee on standards for nutritional studies. Journal of Nutrition 107, 1340-1348.

Anast CS \& Forte LF (1983) Parathyroid function and magnesium depletion in the rat. Endocrinology 113, 184-189.

Anast CS \& Gardner DW (1981) Magnesium metabolism. In Disorders of Mineral Metabolism: Pathophysiology of Calcium, Phosphorus and Magnesium, pp. 423-522 [J Bronner and JW Coburn, editors]. New York, NY: Academic Press.

Black D, Farqharson C \& Robins SP (1989) Excretion of pyridinium crosslinks of collagen in ovariectomized rats as urinary markers for increased bone resorption. Calcified Tissue International 44, 343-347.

Boskey AL, Rimnac CM, Bansal M, Federman M, Lian J \& Boyan BD (1992) Effect of short-term hypomagnesemia on the chemical and mechanical properties of rat bone. Journal of Orthopaedic Research 10, 774-783.

Bunce GE \& King GA (1978) Isolation and partial characterization of kidney stone matrix induced by magnesium deficiency in the rat. Experimental and Molecular Pathology 28, 322-325.

Calabresi E, Lasagni L, Franceschelli F, Bartolini L \& Serio M (1994) Use of an internal standard to measure pyridinoline and deoxypyridinoline in urine (letter). Clinical Chemistry 40, 336-337.

Carpenter TO, Mackowiak SJ, Troiano N \& Gundberg CM (1992) Osteocalcin and its message: relationship to bone histology in magnesium-deprived rats. American Journal of Physiology 263, E107-E114.

Clark T \& Belanger LF (1967) The effects of alterations in dietary magnesium on calcium phosphorus and skeletal metabolism. Calcified Tissue Research 1, 204-218.

Cleveland LE, Goldman JD \& Borrud LG (1996) Data Tables: Results from USDA's 1994 Continuing Survey of Food Intakes by Individuals and 1994 Diet and Health Knowledge Survey. Beltsville, MD: Agriculture Research Service, U.S. Department of Agriculture.

Cohen L (1988) Recent data on magnesium and osteoporosis. Magnesium Research 1, 85-87.

Cohen L \& Laor A (1990) Correlation between bone magnesium concentration and magnesium retention in the intravenous magnesium load test. Magnesium Research 3, 271-274.

Colwell R, Russell RGG \& Eastell R (1993) Factors affecting the assay of urinary 3-hydroxypyridinium cross-links of collagen as markers of bone resorption. European Journal of Clinical Investigation 23, 341-349.

Dallemagne MJ \& Fabry C (1956) Structure of bone salts. In Bone Structure and Metabolism, pp. 14-32 [GEW Walstenholme and CM O'Connor, editors]. Boston, MA: Little, Brown, and Co.

Ducy P, Desbois C, Boyce B, Pinero G, Story B, Dunstan C, Smith E, Bonadio J, Goldstein S, Gundberg C, Bradley A \& Karsenty $G$ (1996) Increased bone formation in osteocalcin-deficient mice. Nature 382, 448-452.

Egger CD, Mühlbauer RC, Felix R, Delmas PD, Marks SC \& Fleisch H (1994) Evaluation of urinary pyridinium crosslink excretion as a marker of bone resorption in the rat. Journal of Bone and Mineral Research 9, 1211-1219.

Elin R (1969) Biochemical and pathological studies in magnesium deficiency in the rat. PhD Thesis, University of Minnesota.

Fleet JC \& Hock JM (1994) Identification of osteocalcin mRNA in nonosteoid tissue of rats and humans by reverse transcriptionpolymerase chain reaction. Journal of Bone and Mineral Research 9, 1565-1573.

Gregory J, Foster K, Tyler H \& Wiseman M (1990) The Dietary and Nutritional Survey of British Adults. London: H.M. Stationery Office.

Hahn TJ, Chase LR \& Avioli LV (1972) Effect of magnesium depletion on responsiveness to parathyroid hormone in parathyroidectomized rats. Journal of Clinical Investigation $\mathbf{5 1}$, 886-891.

Heaton FW (1965) Effect of magnesium deficiency on plasma alkaline phosphatase activity. Nature 207, 1292-1293.

Héroux D, Peter D \& Tanner A (1975) Effect of chronic suboptimal intake of magnesium on magnesium and calcium content of bone and on bone strength of the rat. Canadian Journal of Physiology and Pharmacology 53, 304-310.

Institute of Medicine (1997) Dietary Reference Intakes: Calcium, Magnesium, Phosphorus, Vitamin D, and Fluoride. Washington, DC: Food and Nutrition Board, National Academy Press.

Jones JE, Schwartz R \& Krook L (1980) Calcium homeostasis and bone pathology in magnesium deficient rats. Calcified Tissue International 31, 231-238.

Kenny MA, McCoy H \& Williams L (1994) Effects of magnesium deficiency on strength, mass, and composition of rat femur. Calcified Tissue International 54, 44-49.

Kimura M, Ujihara M \& Yokoi K (1996) Tissue manganese levels and liver pyruvate carboxylase activity in magnesium-deficient rats. Biological Trace Element Research 52, 171-179.

Kimura M \& Itokawa Y (1989) Inefficient utilization of iron and minerals in magnesium deficient rats. In Magnesium in Health and Disease, pp. 95-102 [Y Itokawa and J Durlach, editors]. London: John Libbey.

Koh ET, Reiser S \& Fields M (1989) Dietary fructose as compared to glucose and starch increases the calcium content of kidney of magnesium-deficient rats. Journal of Nutrition 119, 1173-1178.

Lai CC, Singer L \& Armstrong WD (1975) Bone composition and phosphatase activity in magnesium deficiency in rats. Journal of Bone and Joint Surgery 57A, 516-522.

Larvor P \& Labat M (1978) The influence of magnesium deficiency on calcium metabolism in the rat. Annales de Biologie Animale Biochimie Biophysique 18, 149-155.

Lerma A, Planells E, Aranda P \& Llopis J (1993) Evolution of Mg deficiency in rats. Annals of Nutrition and Metabolism 37, 210-217.

MacManus J \& Heaton FW (1969) The effect of magnesium deficiency on calcium homeostasis in the rat. Clinical Science 36, 297-306. 
MacManus J, Heaton FW \& Lucas PW (1971) A decreased response to parathyroid hormone in magnesium deficiency. Journal of Endocrinology 49, 253-258.

Manicourt DH, Orloff S, Brauman J \& Schoutes A (1981) Bone mineral content of the radius: good correlations with physiochemical determinations in iliac crest trabecular bone of normal and osteoporotic subjects. Metabolism 30, 57-62.

Neuman WF \& Mulryan FJ (1971) Synthetic hydroxyapatite crystals. IV. Magnesium incorporation. Calcified Tissue Research 7, 133-138.

Pesce A \& Kaplan LA (1987) Methods in Clinical Chemistry. St Louis, MO: C.V. Mosby Co.

Planells E, Llopis J, Perán F \& Aranda P (1995) Changes in tissue calcium and phosphorus content and plasma concentrations of parathyroid hormone and calcitonin after long-term magnesium deficiency in rats. Journal of the American College of Nutrition 14, 292-298.

Power MJ \& Fottrell PF (1991) Osteocalcin: diagnostic methods and clinical applications. Critical Reviews in Clinical Laboratory Sciences 28, 287-335.

Rayssiguier Y \& Larvor P (1978) Mineral bone composition and some elements of calcium metabolism in magnesium-deficient growing rats. Annales de Biologie Animale Biochimie Biophysique 18, 157-166.

Rayssiguier Y, Thomasset M, Garel JM \& Barlet JP (1982) Plasma parathyroid hormone levels and intestinal calcium binding protein in magnesium-deficient rats. Hormone and Metabolic Research 14, 379-382.

Reginster JY, Strause L, Deriosy R, Lecart MP, Saltman P \& Franchiomont P (1989) Preliminary report of decreased serum magnesium in postmenopausal osteoporosis. Magnesium 8, 106-109.

Robins SP \& New SA (1997) Markers of bone turnover in relation to bone health. Proceedings of the Nutrition Society 56, 903-914.

Robins SP, Stead DA \& Duncan A (1994) Precautions in using an internal standard to measure pyridinoline and deoxypyridinoline in urine [letter]. Clinical Chemistry 40, 2322-2323.
Rude RK (1998) Magnesium deficiency: a cause of heterogeneous disease in humans. Journal of Bone and Mineral Research 13, 749-758.

Snedecor GW \& Cochran WG (1967) Statistical Methods. Ames, IA: Iowa State University Press.

Snyder FH \& Tweedy WR (1942) The effects of magnesiumdeficient diet on the serum phosphatase activity in the Albino rat. Journal of Biological Chemistry 146, 639-647.

Sojka JE \& Weaver CM (1995) Magnesium supplementation and osteoporosis. Nutrition Reviews 53, 71-74.

Stendig-Lindberg G, Tepper R \& Leichter I (1993) Trabecular bone density in a two year controlled trial of peroral magnesium in osteoporosis. Magnesium Research 6, 155-163.

Tucker K, Kiel DP, Hannan MT \& Felson DT (1995) Magnesium intake is associated with bone mineral density (BMD) in elderly women. Journal of Bone Mineral Research 10, S466.

Trudeau DL \& Freier EF (1967) Determination of Ca in urine and serum by atomic absorption spectrophotometry (AAS). Clinical Chemistry 13, C101-C114.

Van Dokkum W (1995) The intake of selected minerals and trace elements in European countries. Nutrition Research Reviews 8 , 271-302.

Vormann J, Förster C, Zippel U, Lozo E, Günther T, Merker H-J \& Stahlmann R (1997) Effects of magnesium deficiency on magnesium and calcium content in bone and cartilage in developing rats in correlation to chondrotoxicity. Calcified Tissue International 61, 230-238.

Wallach S (1990) Effects of magnesium on skeletal metabolism. Magnesium 9, 1-14.

Walser M (1967) Magnesium metabolism. Ergebnisse der Physiologie Biologischen Chemie und Experimentellen Pharmakologie 59, 186-296.

Weissman N \& Pileggi VJ (1974) Inorganic ions. In Clinical Chemistry: Principles and Techniques, pp. 639-755 [RJ Henry, DC Cannon and JW Winkelman, editors]. MD: Harper and Row.

Welsh JJ \& Weaver VM (1988) Adaptation to low dietary calcium in magnesium-deficient rats. Journal of Nutrition 118, 729-734. 